\title{
Anisakiasis: Report of 15 Gastric Cases Caused by Anisakis Type I Larvae and a Brief Review of Korean Anisakiasis Cases
}

\author{
Woon-Mok Sohn",*, Byoung-Kuk Na', Tae Hyo Kim², Tae-Joon Park ${ }^{3}$ \\ ${ }^{1}$ Department of Parasitology and Tropical Medicine, and Institute of Health Sciences, Gyeongsang National University School of Medicine, \\ Jinju 660-751, Korea; 'Department of Internal Medicine and Institute of Health Sciences, Gyeongsang National University School of Medicine, \\ Jinju 660-751, Korea; ${ }^{3}$ Murup Hospital, Changwon 631-869, Korea
}

\begin{abstract}
The present study was performed to report 15 anisakiasis cases in Korea and to review the Korean cases reported in the literature. Total 32 Anisakis type I larvae were detected in the stomach of 15 patients by the endoscopy. Single worm was detected from 12 cases, and even 9 larvae were found from 2 cases. Epigastric pain was most commonly manifested in almost all cases, and hemoptysis and hematemesis were seen in 1 case each. Symptom manifestations began at 10-12 hr after eating fish in 73.3\% cases. Endoscopy was performed 1-2 days after the symptom onset in most cases. The common conger, Conger myriaster, was the probable infection source in 7 cases. In the review of Korean anisakiasis cases, thus far, total 645 cases have been reported in 64 articles. Anisakis type I larva was the most frequently detected (81.3\%). The favorable infection site of larvae was the stomach (82.4\%). The common conger was the most probable source of human infections (38.6\%). Among the total 404 cases which revealed the age and sex of patients, 185 (45.8\%) were males, and the remaining 219 (54.2\%) were female patients. The age prevalence was the highest in forties (34.7\%). The seasonal prevalence was highest in winter (38.8\%). By the present study, 15 cases of gastric anisakiasis are added as Korean cases, and some epidemiological characteristics of Korean anisakiasis were clarified.
\end{abstract}

Key words: Anisakiasis, Anisakis type I larva, review, Korean anisakiasis

\section{INTRODUCTION}

Anisakiasis is one of the fishborne zoonotic diseases, especially in localities, where people have a custom of eating raw marine fish and squids like in Japan and Korea [1,2]. The concept of this disease was first raised by van Thiel et al. [3] in the Netherlands. After then, human infection cases were consequently reported in England, Japan, and the Republic of Korea (Korea) [4-7]. Nowadays, this zoonotic nematode disease is a clinical concern worldwide, including Japan, Korea, the Netherlands, Spain, France, Italy, Germany, and the United States. Especially in Japan, it has been known that more than 2,000 cases occurred annually [1,2].

Since the first human case was reported by Kim et al. [7] in 1971, until now numerous patients have increasingly occurred

- Received 29 April 2015, revised 21 May 2015, accepted 16 June 2015.

*Corresponding author (wmsohn@gnu.ac.kr)

(c) 2015, Korean Society for Parasitology and Tropical Medicine

This is an Open Access article distributed under the terms of the Creative Commons Attribution Non-Commercial License (http://creativecommons.org/licenses/by-nc/3.0) which permits unrestricted non-commercial use, distribution, and reproduction in any

medium, provided the original work is properly cited. in Korea. Especially the increasing tendency of cases was accelerated by the common use of endoscopy in the diagnosis and treatment of gastric anisakiasis [8]. Chung et al. [9] and Seol et al. [10] reported 27 and 20 cases that occurred in Busan Metropolitan City. Im et al. [11,12] analyzed 39 and 107 cases of gastric anisakiasis occurred in Jeju-do. Song et al. [13] reported total 39 cases residing in Incheon Metropolitan City. Recently, Lee et al. [14] analyzed total 141 cases diagnosed by the endoscopy in a local clinic in Jinju-si, Gyeongsangnam-do. Most recently, Lim et al. [15] clarified the etiologic agents of 16 human anisakiasis in Korea, 15 of which were confirmed as Anisakis pegreffii larvae and only 1 was Anisakis simplex larva using a molecular analysis. In this study, we report an additional 15 gastric anisakiasis cases that occurred in Gyeongsangnam-do, and then analyzed the epidemiologic and clinical characteristics of Korean anisakiasis cases through a literature review.

\section{CASE RECORD}

Total 15 anisakiasis cases were diagnosed with the gastric endoscopy in the Gyeongsang National University Hospital 
Table 1. Summary of the 15 cases of gastric anisakiasis caused by Anisakis type I larvae

\begin{tabular}{|c|c|c|c|c|c|c|c|c|}
\hline $\begin{array}{l}\text { Case } \\
\text { no. }\end{array}$ & Age & Sex & $\begin{array}{l}\text { Date of } \\
\text { occurrence }\end{array}$ & Fish eaten & Chief complaints & $\begin{array}{l}\text { Time from } \\
\text { eating fish to } \\
\text { symptom onset }\end{array}$ & $\begin{array}{l}\text { Time from } \\
\text { symptom onset } \\
\text { to endoscopy }\end{array}$ & $\begin{array}{l}\text { Detection } \\
\text { site of worm } \\
\text { in stomach }\end{array}$ \\
\hline 1. & 33 & M & Oct., '99 & Common conger & Severe epigastric pain & $12 \mathrm{hr}$ & 2 days & Middle body G.C. \\
\hline 2. & 47 & M & Feb., '00 & $\begin{array}{l}\text { Several kinds } \\
\text { of marine fishes }\end{array}$ & $\begin{array}{l}\text { Epigastric pain, } \\
\text { nausea \& vomiting }\end{array}$ & $12 \mathrm{hr}$ & 3 days & $\begin{array}{l}\text { Upper body } \\
\text { Anterior wall }\end{array}$ \\
\hline 3. & 37 & M & Jun., '00 & Common conger & Hemoptysis & $10 \mathrm{hr}$ & 1 day & Lower body G.C ${ }^{a}$ \\
\hline 4. & 27 & M & Jun., '00 & $\begin{array}{l}\text { Several kinds of } \\
\text { marine fishes }\end{array}$ & Epigastric pain & $12 \mathrm{hr}$ & $36 \mathrm{hr}$ & Upper body G.C ${ }^{a}$ \\
\hline 5. & 41 & M & Aug., '00 & $\begin{array}{l}\text { Several kinds of } \\
\text { marine fishes }\end{array}$ & $\begin{array}{l}\text { Epigastric pain } \\
\& \text { nausea }\end{array}$ & $24 \mathrm{hr}$ & 3 days & Upper body G.C ${ }^{a}$ \\
\hline 6. & 28 & M & Oct., '00 & Common conger & Epigastric pain & $6 \mathrm{hr}$ & $12 \mathrm{hr}$ & Middle body G.C ${ }^{a}$ \\
\hline 7. & 55 & M & Jun., '01 & $\begin{array}{l}\text { Several kinds of } \\
\text { marine fishes }\end{array}$ & Severe epigastric pain & $12 \mathrm{hr}$ & 2 days & Lower body G.C ${ }^{a}$ \\
\hline 8. & 59 & $M$ & Jan., '02 & Common conger & Epigastric pain & $12 \mathrm{hr}$ & $12 \mathrm{hr}$ & Middle body G.C ${ }^{a}$ \\
\hline 9. & 45 & $\mathrm{~F}$ & Sep., '02 & $\begin{array}{l}\text { Common conger \& } \\
\text { Pacific cutlass fish }\end{array}$ & $\begin{array}{l}\text { Epigastric pain \& } \\
\text { hematemesis }\end{array}$ & $6 \mathrm{hr}$ & 3 days & Uncertain $^{\mathrm{b}}$ \\
\hline 10. & 36 & $\mathrm{~F}$ & Oct., '02 & $\begin{array}{l}\text { Several kinds of } \\
\text { marine fishes }\end{array}$ & Severe epigastric pain & $12 \mathrm{hr}$ & 2 days & Lower body G.C ${ }^{a}$ \\
\hline 11. & 42 & M & Apr., '03 & Anchovy & $\begin{array}{l}\text { Epigastric pain, } \\
\text { nausea \& vomiting }\end{array}$ & $10 \mathrm{hr}$ & 1 day & $\begin{array}{l}\text { Upper body } \\
\text { Anterior wall }\end{array}$ \\
\hline 12. & 51 & M & May., '04 & Common conger & Severe epigastric pain & $12 \mathrm{hr}$ & 1 day & Uncertain $^{\mathrm{b}}$ \\
\hline 13. & 61 & M & Mar., '09 & Anchovy & $\begin{array}{l}\text { Epigastric pain, } \\
\text { nausea \& vomiting }\end{array}$ & $10 \mathrm{hr}$ & 1 day & $\begin{array}{l}\text { Upper body } \\
\text { lesser curvature }\end{array}$ \\
\hline 14. & 52 & M & Dec., '09 & Uncertain & Epigastric pain \& nausea & $7 \mathrm{hr}$ & 1 day & Lower body G.C ${ }^{a}$ \\
\hline 15. & 46 & $\mathrm{~F}$ & Jan., '10 & Common conger & Severe epigastric pain & $12 \mathrm{hr}$ & 2 days & Uncertain \\
\hline
\end{tabular}

aGreater curvature.

${ }^{b}$ Nine larvae were detected in each case.

Table 2. Measurements ${ }^{a}$ and indices of Anisakis type I larvae from human cases

\begin{tabular}{|c|c|c|c|}
\hline Items & 3rd stage $(n=7)$ & 4th stage $(n=7)$ & Chai et al. (1986) [7] \\
\hline Body length & $16.55-29.0$ (23.98) & $17.10-22.75$ (20.68) & $13.4-25.0(20.7)$ \\
\hline Body width & $0.35-0.58(0.48)$ & $0.45-0.58(0.50)$ & $0.23-0.54(0.41)$ \\
\hline $\begin{array}{l}\text { Esophagus (total) } \\
\text { Muscular part } \\
\text { Ventricular part }\end{array}$ & $\begin{array}{c}2.0-3.0(2.46) \\
1.55-2.08(1.85) \\
0.45-0.92(0.62)\end{array}$ & $\begin{array}{l}2.35-3.38(2.88) \\
1.75-2.50(2.18) \\
0.55-0.88(0.71)\end{array}$ & $\begin{array}{l}1.86-2.70(2.36) \\
1.27-1.89(1.65) \\
0.57-0.83(0.71)\end{array}$ \\
\hline Tail & $0.08-0.12(0.10)$ & $0.10-0.15(0.13)$ & $0.07-0.12(0.10)$ \\
\hline Mucron & $20-25(21) \mu \mathrm{m}$ & - & - \\
\hline \multicolumn{4}{|l|}{ Indices $^{c}$} \\
\hline$a$ & $37.59-58.0(49.96)$ & $34.20-50.0(41.36)$ & $43.7-66.3(50.6)$ \\
\hline$\beta_{1}$ & $7.20-10.04(9.75)$ & $6.63-8.24(7.18)$ & $7.02-9.92$ (8.73) \\
\hline$\beta_{2}$ & $10.08-13.94(12.96)$ & $8.95-10.56(9.49)$ & $10.01-14.70(12.5)$ \\
\hline$\beta_{3}$ & $24.34-40.34$ (38.68) & $23.58-37.50(29.13)$ & $25.5-39.4(29.2)$ \\
\hline$Y$ & $157.9-290.0(239.8)$ & $145.57-186.5(159.08)$ & $167.6-271.3(213.4)$ \\
\hline
\end{tabular}

aUnit is $\mathrm{mm}$.

bfrom the yellow corvine, Pseudosciaena polyactis.

'Legend: $\alpha=$ Body length/Body width; $\beta 1=$ Body length/Esophagus; $\beta 2=$ Body length/Muscular part of esophagus; $\beta 3=$ Body length/Ventriculus; $\gamma=$ Body length/Tail.

and a local clinic located in Jinhae-gu, Changwon-si, Gyeongsangnam-do from October 1999 to January 2010. Most of the cases (80\%) were men, and only 3 were women. Total 32 Anisakis type I larvae were detected in the stomach of 15 patients. A single worm was detected from 12 cases, 2 worms from 1 case, and even 9 larvae were found from 2 cases. Epigastric pain was the most common symptom in almost all cases, and nausea and vomiting were accompanied in some cases. Hemoptysis and hematemesis occurred in 1 case each. Symptom manifestations began at 10-12 hr after eating fish in most cases 
Table 3. Number of anisakiasis cases and number of papers reported among the Korean literature

\begin{tabular}{|c|c|c|}
\hline Duration of report & $\begin{array}{l}\text { No. of cases (\%) } \\
\text { reported }\end{array}$ & $\begin{array}{l}\text { No. of papers (\%) } \\
\text { published }\end{array}$ \\
\hline 1971 & $1 \quad(0.2)$ & $1 \quad(1.6)$ \\
\hline 1980-1989 & 77 (11.9) & $18(28.1)$ \\
\hline 1990-1999 & 249 (38.6) & $25 \quad(39.1)$ \\
\hline 2000-2009 & 163 (25.3) & $10(15.6)$ \\
\hline 2010 and later & 155 (24.0) & $10(15.6)$ \\
\hline Total & $645(100)$ & $64(100)$ \\
\hline
\end{tabular}

Table 4. Anisakiasis cases by the occurrence localities

\begin{tabular}{lrl}
\hline Locality & No. of cases (\%) \\
\hline Jeju-do & 217 & $(34.4)$ \\
Gyeongsangnam-do (Jinju-si) & 144 & $(22.8)$ \\
Seoul & 126 & $(20.0)$ \\
Busan & 64 & $(10.1)$ \\
Incheon & 41 & $(6.5)$ \\
Gyeongsangbuk-do (Pohang-si) & 20 & $(3.2)$ \\
Daegu & 5 & $(0.8)$ \\
Gwangju & 4 & $(0.6)$ \\
Daejeon & 2 & $(0.3)$ \\
Jeollabuk-do & 2 & $(0.3)$ \\
Gangwon-do & 2 & $(0.3)$ \\
Others & 4 & $(0.6)$ \\
Total & 631 & $(100)$ \\
\hline
\end{tabular}

aGyeonggi-do (Uijeongbu-si); Chungcheongbuk-do (Chungju-si), Chungcheongnam-do (Cheonan-si) and Jeollanam-do (Suncheon-si) each 1 case.

(73.3\%). Endoscopy was performed in 1-2 days after symptom onset in most cases $(66.7 \%)$. As the probable source of infection, 7 (46.7\%) and 2 (13.3\%) cases recalled that they had eaten raw common conger, Conger myriaster, and anchovy, respectively. However, 6 cases could not remember the exact species of fish; several kinds of fish mixed or uncertain. The case information is summarized in Table 1. Among the total 32 Anisakis type I larvae (either the 3rd or 4th-stage), 7 were morphologically observed and measured with a micrometer (Table 2).

\section{Review of Korean anisakiasis cases}

The articles of Korean anisakiasis cases were basically searched through PubMed site using the internet. The references in all articles were strictly seen to prevent missing cases. Until now, a total of 645 cases have been reported in 64 articles since the first case recorded by Kim et al. [8] in 1971. During 1990-1999, a total of 249 cases (38.6\%) were reported in
Table 5. Age and sex distribution of patients

\begin{tabular}{lccrr}
\hline \multirow{2}{*}{ Age (years) } & \multicolumn{3}{c}{ No. of cases (\%) } \\
\cline { 2 - 5 } & Male & Female & \multicolumn{2}{c}{ Total } \\
\hline Below 19 & 1 & 6 & 7 & $(1.7)$ \\
$20-29$ & 19 & 20 & 39 & $(9.7)$ \\
$30-39$ & 62 & 71 & $133(32.9)$ \\
$40-49$ & 68 & 72 & $140(34.7)$ \\
$50-59$ & 22 & 38 & $60(14.9)$ \\
Over 60 & 13 & 12 & 25 & $(6.2)$ \\
Total & $185(45.8)$ & $219(54.2)$ & $404(100)$ \\
\hline
\end{tabular}

Table 6. Fishes or cephalopods, the probable source of infection, consumed by anisakiasis cases

\begin{tabular}{lrl}
\hline Fishes (scientific name) & No. of cases (\%) \\
\hline Common conger (Conger myriaster) & $120(38.6)$ \\
Croaker (Pseudosciaena spp.) & 36 & $(11.6)$ \\
Squid & 32 & $(10.3)$ \\
Yellowtail (Seriola spp.) & 30 & $(9.7)$ \\
Flatfish & 17 & $(5.5)$ \\
Pacific cod (Gadus macrocephalus) & 6 & $(1.9)$ \\
Anchovy (Engraulis japonica) & 4 & $(1.3)$ \\
Rockfish (Sebastes spp.) & 4 & $(1.3)$ \\
Sea breams & 3 & $(1.0)$ \\
Pacific cutlass fish (Trichiurus lepturus) & 3 & $(1.0)$ \\
Gizzard shad (Konosirus punctatus) & 2 & $(0.6)$ \\
Skates & 2 & $(0.6)$ \\
Others $^{a}$ & 5 & $(1.6)$ \\
Several species of fish mixed & 47 & $(15.1)$ \\
Total & $311(100)$ \\
\hline
\end{tabular}

aHalichoeres tenuispinis (motleystripe rainbowfish), Miichthys miiuy (brown croaker), mullet, tuna and Octopus vulgaris (common octopus) each 1 case.

25 papers (39.1\%). The number of anisakiasis cases reported in the Korean literature is shown in Table 3. The incidence rate was the highest in Jeju-do (34.4\%), followed by in Gyeongsangnam-do (22.8\%), Seoul (20.0\%), Busan (10.1\%), Incheon (6.5\%), Gyeongsangbuk-do (3.2\%), and other 9 administrative regions (0.16-0.79\%) (Table 4). Among a total of 404 cases which revealed the age and sex of patients, 185 (45.8\%) were men and the remaining 219 (54.2\%) were women. The age prevalence was the highest in forties (34.7\%), followed by thirties (32.9\%), fifties (14.9\%), twenties (9.7\%), over sixty (6.2\%), and teens (1.7\%) (Table 5). As the probable source of human infections, the common conger was most frequently mentioned by patients (38.6\%), followed by croaker (11.6\%), squid (10.3\%), yellowtail (9.7\%), flatfish (flounder: $5.5 \%$ ), and the other 12 species of marine fish (Table 6). The etiologic larval type was designated in 203 cases in the lit- 
Table 7. Morphologic identification of anisakid larvae among the literature

\begin{tabular}{|c|c|}
\hline Type of larvae & No. (\%) of larvae identified \\
\hline Anisakis type I & $165(81.3)^{a}$ \\
\hline Anisakis type II & $8 \quad(3.9)$ \\
\hline Terranova type A & $24(11.8)$ \\
\hline Anisakis sp. & $3 \quad(1.5)$ \\
\hline Contracaecum sp. & $3 \quad(1.5)$ \\
\hline Total & $203(100)$ \\
\hline
\end{tabular}

${ }^{a} 15$ cases of $A$. pegreffii were included.

Table 8. Location of worms detected

\begin{tabular}{lrc}
\hline Location & No. (\%) of cases \\
\hline Stomach & 333 & $(82.4)$ \\
Small intestine $^{\mathrm{a}}$ & 46 & $(11.4)$ \\
Gastro-esophageal junction & 14 & $(3.5)$ \\
Large intestine $^{\mathrm{b}}$ & 6 & $(1.5)$ \\
Esophagus $^{\mathrm{O}}$ & 2 & $(0.5)$ \\
Others $^{\mathrm{c}}$ & 3 & $(0.7)$ \\
Total & $404(100)$
\end{tabular}

alleum (12 cases); jejunum and duodenum (2 cases each). ${ }^{\mathrm{b}}$ Colon (5 cases); cecum (1 case).

'Palatine tonsil, ileo-cecal region and mesocolic lymph node (1 case each).

eratures. Among them, 165 cases (81.3\%) were due to Anisakis type I larvae, 24 (11.8\%) were by Terranova type A, and 8 cases (3.9\%) were by Anisakis type II. Each of the 3 cases were due to Contracaecum sp. and Anisakis sp. larvae (Table 7). The predilection site was the stomach (82.4\%), followed by small intestines $(11.4 \%)$, gastro-esophageal junction (3.5\%), large intestines (1.5\%), esophagus (0.5\%), and others including the palatine tonsil, ileo-cecal region, and mesocolic lymph node (Table 8$)$. In most cases (65.7\%), symptoms were manifested before $12 \mathrm{hr}$ from eating raw flesh of fish (Table 9). The seasonal prevalence was the highest in winter $(38.8 \%)$, followed by spring (23.1\%), autumn (19.9\%), and summer (18.2\%) (Table 10).

\section{DISCUSSION}

By the present study, 15 cases of gastric anisakiasis have been added among the Korean anisakiasis cases. Only 1 anisakid larva was detected in most of the cases. However, interestingly, even 9 worms were recovered from each of 2 cases. Like in the previous studies, epigastric pain was the chief complain and most commonly manifested in almost all cases.
Table 9. The time intervals from eating raw flesh of fish to onset of symptoms

\begin{tabular}{lc}
\hline Time (hr) & No. $(\%)$ of cases \\
\hline$\leq 6$ & $109(32.4)$ \\
$7-12$ & $112(33.3)$ \\
$13-24$ & $51 \quad(15.2)$ \\
$25-72$ & $36(10.7)$ \\
$\geq 73$ (chronic) & $28 \quad(8.3)$ \\
Total & $336(100)$ \\
\hline
\end{tabular}

Table 10. The frequency of patients by season

\begin{tabular}{lc}
\hline Season & No. (\%) of cases \\
\hline Spring & $71(23.1)$ \\
Summer & $56(18.2)$ \\
Autumn & $61(19.9)$ \\
Winter & $119(38.8)$ \\
Total & $307(100)$ \\
\hline
\end{tabular}

However, hemoptysis and hematemesis were revealed in 1 case each. It has been known that severe bleeding can occur due to anisakid larva infection in patients with gastric ulcer [15,17-19]. Therefore, these 2 cases may have had some ulcer lesions in their stomach. Time intervals from fish eating to symptom onset and from symptom onset to endoscopy were 10-12 hr and 1-2 days in most cases. These findings were in accordance with previous studies $[11,15]$. The common conger, C. myriaster, is suspected as the most probable source of infection in 7 patients (46.7\%). Until now, in Korea, a total of 645 cases have been reported in 64 papers since the first case reported by Kim et al. [8]. Accordingly, as 15 cases have been added by this study, the total number of anisakiasis cases in Korea became 660 cases in the Korean literature.

Among 32 Anisakis type I larvae detected, 7 were in the fourth-stage $\left(\mathrm{L}_{4}\right)$, which had molted in the stomach of the patients. They were similar in size with the third stage larvae $\left(\mathrm{L}_{3}\right)$, but they can be morphologically differentiated from $\mathrm{L}_{3}$ by the following characteristic features: (1) absence of the boring tooth at the anterior end and the mucron at the posterior end; (2) the presence of the 3 well-defined lips; (3) the appearance of transverse striations on the cuticular body surface; (4) the appearance of altered ventriculus and intestine (Table 2) $[20,21]$.

The number of human anisakiasis cases (38.6\%) and papers (39.1\%) published in Korea were the highest during 19901999, while 163 cases (25.3\%) were reported in 10 articles (15.6\%) during 2000-2009, and only 77 (11.9\%) were record- 
ed in 18 papers (28.1\%) during 1980-1989. During 19801989, each anisakiasis case was meaningful and could be easily published in journals. However, recently, anisakiasis case reports were done after gathering large numbers of cases to demonstrate something different and unique findings [15,2224]. So, the number of articles published was not so many during the recent years.

The higher incidence rate was found in coastal areas, such as Jeju-do, Jinju, (Gyeongsangnam-do), Busan, Incheon, and Pohang (Gyeongsangbuk-do), where people favorably consume raw flesh of marine fish. Moreover, the presence of medical authorities, who are able to produce manuscripts describing case reports, is also an important factor $[10-15,25,26]$.

Among total 404 cases that revealed the age and sex of patients, the number of women was slightly more than that of men, with the ratio of women to men of 1.18:1. This finding was largely influenced by the report of Lee et al. [15], who analyzed 141 gastrointestinal anisakiasis cases in a local clinic in Jinju-si, Gyeongsangnam-do. In their study, the number of women (91 cases) was much more than that of men (50) [15]. Meanwhile, Im et al. [13] reported total 107 cases in Jeju-do, the number of women (47 cases) was lesser than that of men (60), with the ratio of women to men of 0.78:1 [13]. Regarding the age prevalence, most of the cases (67.6\%) were patients in their thirties and forties.

Various species of marine fish and cephalopods have been known as the sources of human infections. In European countries, especially in The Netherlands and Spain, raw or pickled fish, such as herring, hake, anchovy, and cod, are known to be important infection sources $[3,27]$. In Japan, some species of flounders, Japanese common squid, the Pacific cod, and the bluefin tuna are the main sources in Hokkaido, and the spotted sardine, the chub mackerel, the horse mackerel, the oceanic bonito, and the chum salmon are important infection sources in Kyushu $[28,29]$. However in Korea, the common conger was the most frequently mentioned by the patients as the probable source of infections, followed by the croaker, squid, yellowtail, flatfish, and the other 12 species of marine fish.

It has been known that the majority of human infections were caused by the larvae of A. simplex (Anisakis type I), and rarely or occasionally by those of Anisakis physeteris (Anisakis type II), and Pseudoterranova decipiens (Terranova type A) [13,14,30-33]. In the present review, $81.3 \%$ cases were due to Anisakis type I larvae, and $11.8 \%$ and $3.9 \%$ were by Terranova type A and Anisakis type II larvae, respectively. Recently, the etiologic agents of human anisakiasis in Korea, which were morphologically Anisakis type I larvae, were molecularly confirmed to be A. pegreffii larvae [16]. Moreover, most of the Anisakis type I larvae detected in 7 fish species from the Yellow Sea and the South Sea in Korea were also identified as A. pegreffii [34]. Although only 15 human cases were enrolled by Lim et al. [16], it seems that most of the Korean ansakiasis cases may be caused by A. pegreffii based on the above 2 molecular studies. Molecular methods should be more frequently adopted to identify the causative agent of human anisakiasis in the future.

The stomach was the main site of infection in most cases (82.4\%). However, anisakid larvae were found rarely in other digestive organs, i.e., esophagus, small intestines, large intestines, and mesocolic lymph node. In most cases, symptoms were manifested before $12 \mathrm{hr}$ from eating of the raw fish flesh. The seasonal prevalence was the highest in winter, followed by in spring, autumn, and summer. This seasonality seemed directly related to the frequency of eating raw fish flesh in each season. The consumption of raw fish meat is more popular in winter season rather than in summer season in Korea because of the anxiety for food poisoning.

\section{CONFLICT OF INTEREST}

We have no conflict of interest related to this work.

\section{REFERENCES}

1. Chai JY, Murrell KD, Lymbery AJ. Fish-borne parasitic zoonoses: status and issues. Int J Parasitol 2005; 35: 1233-1254.

2. Sohn WM, Chai JY. Anisakiosis (Anisakidosis). In Palmer SR, Soulsby L, Torgerson PR, Brown DWG eds, Oxford Textbook of Zoonoses-Biology, Clinical Practice, and Public Health Control. London, UK. Oxford University Press. 2011, pp 774-786.

3. van Thiel PH, Kuiper FC, Roskam RT. A nematode parasitic to herring, causing acute abdominal syndromes in man. Trop Geogr Med 1960; 2: 97-113.

4. Ashby BS, Appleton PJ, Dawson I. Eosinophilic granuloma of gastro-intestinal tract caused by herring parasite Eustoma rotundatum. Br Med J 1964; 1: 1141-1145.

5. Asami K, Watanuki T, Sakai H, Imano H, Okamoto R. Two cases of stomach granuloma caused by Anisakis-like larvae nematodes in Japan. Am J Trop Med Hyg 1965; 14: 119-123.

6. Yokogawa M, Yoshimura H. Anisakis-like larvae causing eosinophilic granuloma in the stomach of man. Am J Trop Med Hyg 1965; 14: 770-773. 
7. Chai JY, Chu YM, Sohn WM, Lee SH. Larval anisakids collected from the yellow corvina in Korea. Korean J Parasitol 1986; 24: 1-11.

8. Kim CH, Chung BS, Moon YI, Chun SH. A case report on human infection with Anisakis sp. in Korea. Korean J Parasitol 1971; 9: 39-43.

9. Lee KH, Koo JT, Song JH, Hyun MS, Jhi CJ. Acute gastric anisakiasis-endoscopic, radiologic diagnosis and it's management. Korean J Int Med 1981; 24: 1220-1227 (in Korean).

10. Chung WC, Oh KY, Chun SW, Kang SB, Chung YK. Clinical observation of gastric anisakiasis. Korean J Int Med 1983; 26: 13941399 (in Korean).

11. Seol SY, Ok SC, Pyo JS, Kim IH, Lee SH, Chung JM, Choi HJ, Jung SJ, Sohn WM. Twenty cases of gastric anisakiasis caused by Anisakis type I larva. Korean J Gastroent 1994; 26: 17-24 (in Korean).

12. Im KI, Yong TS, Shin HJ, Kim BH, Moon SI. Gastric anisakiasis in Korea with review of 47 cases. Yonsei Rep Trop Med 1990; 21: 1-7.

13. Im KI, Shin HJ, Kim BH, Moon SI. Gastric anisakiasis cases in Cheju-do, Korea. Korean J Parasitol 1995; 33: 179-186 (in Korean).

14. Song TJ, Cho SW, Joo KH. Endoscopic findings of acute gastric anisakiasis-thirty nine cases in Incheon City. Korean J Gastrointest Endosc 1999; 19: 878-884 (in Korean).

15. Lee EJ, Kim YC, Jeong HG, Lee OJ. The mucosal changes and influencing factors in upper gastrointestinal anisakiasis: analysis of 141 cases. Korean J Gastroenterol 2009; 53(2): 90-97 (in Korean).

16. Lim H, Jung BK, Cho J, Yooyen T, Shin EH, Chai JY. Molecular diagnosis of cause of anisakiasis in humans, South Korea. Emerg Infect Dis. 2015; 21: 342-344.

17. Lee SH, Sin HG, Seol SY, Chung JM. A case of gastric anisakiasis causing severe gastric ulcer bleeding. Korean J Gastrointest Endosc 1993; 13: 693-696 (in Korean).

18. Lee HS, Park KS, Jung KT, Yoo SJ, Kho JH, Park BS, Choi WS, Choi DY, Choi HS. A case of chronic gastric anisakiasis with massive bleeding. Korean J Gastrointest Endosc 1993; 13: 697700 (in Korean).

19. Kang DB, Park WC, Lee JK. Chronic gastric anisakiasis provoking a bleeding gastric ulcer. Ann Surg Treat Res 2014; 86: 270-273.

20. Fujino T, Ooiwa T, Ishii Y. Clinical, epidemiological and morphological studies on 150 cases of acute gastric anisakiasis in Fukuoka Prefecture. Jpn J Parasitol 1984; 33: 73-92 (in Japanese).
21. Sohn WM. Ultrastructural changes on the cuticular surface, excretory and digestive organs of Anisakis simplex larvae chronologically recovered from experimental cats. Korean J Electr Microsc 1999; 29: 211-221 (in Korean).

22. Kim T, Song HJ, Jeong SU, Choi EK, Cho YK, Kim HU, Song BC, Kim KS, Kim BS, Kim YR. Comparison of the clinical characteristics of patients with small bowel and gastric anisakiasis in Jeju Island. Gut Liver 2013; 7: 23-29.

23. Choi SC, Lee SY, Song HO, Ryu JS, Ahn MH. Parasitic infections based on 320 clinical samples submitted to Hanyang University, Korea (2004-2011). Korean J Parasitol 2014; 52: 215-220.

24. Lee JS, Kim BS, Kim SH, Park JK, Choi G, Hwang IK, Jeong SY, Hyun CL, Song HJ, Chung YB. Acute invasive small-bowel anisakiasis: clinical and CT findings in 19 patients. Abdom Imaging 2014; 39: 452-458.

25. Han DS, Han YB, Park DI, Kim SH, Kim SS. Clinical study of anisakiasis. J Korean Med Assoc 1988; 31: 645-650 (in Korean).

26. Jang GL, Chung JY, Kim WK, Kim KS, Kim JG, Kim YJ, Park BK, Hwang SS, Kang MK. Clinical observation of 12 cases of gastric anisakiasis. Korean J Int Med 1989; 37: 403-410 (in Korean).

27. Audicana MT, Ansotegui IJ, de Corres LF, Kennedy MW. Anisakis simplex: dangerous-dead and alive? Parasitol Today 2002; 18: 2025.

28. Nagasawa K, Moravec F. Larval anisakid nematodes of Japanese common squid (Todarodes pacificus) from the Sea of Japan. J Parasitol 1995; 81: 69-75.

29. Ishikura H, Takahashi S, Ishikura H. Anisakidae and anisakidosis in Japan. In Proceedings of the 2nd Japan-Korea Parasitologists' Seminar (Forum Cheju-2)-Foodborne parasitic diseases in Japan and Korea. Fukuoka, Japan. 1996, pp 50-63.

30. Kagei N, Sano M, Takahashi Y, Tamura Y, Sakamoto M. A case of acute abdominal syndrome caused by Anisakis type-II larva. Jap J Parasitol 1978; 27: 427-431.

31. Ishikura H, Namiki M. Gastric anisakiasis in Japan. Epidemiology, diagnosis, treatment, Tokyo, Japan. Springer-Verlag, 1989, pp 1-141.

32. Yu JR, Seo M, Kim YW, Oh MH, Sohn WM. A human case of gastric infection by Pseudoterranova decipens larva. Korean J Parasitol 2001; 39: 193-196.

33. Na HK, Seo M, Chai JY, Lee EK, Jeon SM. A case of anisakidosis caused by Pseudoterranova decipiens larva. Korean J Parasitol 2013; 51: 115-117.

34. Sohn WM, Kang JM, Na BK. Molecular analysis of Anisakis type I larvae in marine fish from three different sea areas in Korea. Korean J Parasitol 2014; 52: 383-389. 